\title{
Ungdommens tumlepladser - Frøbjerg Bavnehøj og andre folkelige fest- og idrætspladser på Fyn
}

\section{Af Johnny Wøllekar}

Skal vi så tage fat! Under den overskrift lod A. Nielsen fra Svenstrup i 1933 trykke et indlæg i Ungdom og Idrat, hvor han energisk plæderede for tilvejebringelsen af »virkelige idratspladser « og »ordentlige forhold til badning og svømning «. ${ }^{1}$ Etablering af gedigne idrætsfaciliteter havde, hævdede han, stået på de folkelige gymnastikforeningers $\varnothing$ nskesedler i mange år, men uden de helt store resultater. Derfor måtte der nu tages fat.

Da den frivillige gymnastik vandt frem på landet, var den først og fremmest et supplement til skydeøvelserne i skyttebevægelsen. Derfor var gymnastikken også en vinteraktivitet, som blev udøvet, når den udendørs skydning indstilledes. Vintergymnastikken krævede dog velegnede indendørsfaciliteter, og da de fleste landsbyskoler ikke havde en gymnastiksal, blev de foreningsdrevne forsamlingshuse et naturligt samlingssted for gymnasterne.

Gennem mellemkrigsårene skete der dog en successiv udvidelse af idrætstilbuddene på landet, idet idrætsgrene som håndbold, fodbold og badminton blev introduceret og vandt stor udbredelse. I mellemkrigsårene fik sporten sit endelige gennembrud i Danmark - og det gælder også landsognene. ${ }^{2}$ Samtidig blev gymnastikkens nære tilknytning til skyttebevægelsen løsnet, så gymnastikken ikke længere bare var et supplement til skydeøvelserne. Altsam- men stillede nye og andre krav til idrætsanlæggene på landet, og forsamlingshusene var ikke længere nok.

Ordentlige faciliteter var altafg $ø$ rende for idrættens udfoldelses- og udviklingsmuligheder, og når $\mathrm{A}$. Nielsen og andre gymnastikledere satte gymnastik- og idrætspladser på dagsordenen i mellemkrigsårene, skal det formentlig også ses i lyset af de forandringer som idrætten på landet gennemløb i disse år. Et af tidens nybrud skete indenfor gymnastikken efter 1 . verdenskrig. Fortidens stillestående gymnastik i snævre lokaler virkede efterhånden forældet, og mange talte varmt for idræt $\mathrm{i}$ det grønne og $\mathrm{i}$ fri luft - noget der lå helt i tråd med mellemkrigsårenes grønne bølge, hvor cyklen blev allemandseje, motorcykler opnåelige for mange, og hvor ungdommen i stor stil søgte ud i det fri. Der blev vandret, camperet og dyrket idræt i det fri. ${ }^{3}$

Oprettelsen af gymnastikhøjskolerne i Ollerup (1920) og i Snoghøj (1925) fik afgørende betydning for mellemkrigsårenes modernisering af gymnastikken. På de to skoler, der på det tidspunkt var landets eneste, udklækkedes henholdsvis de mandlige og kvindelige delingsførere, der var rygraden i det daglige arbejde inden for den folkelige gymnastikbevægelse. Højskolen i Ollerup blev et kraftcentrum for gymnastikken på landet, idet Niels Bukhs såkaldt primitive gymnastik hurtigt slog 
igennem. Den lingske stillingsgymnastik blev i Niels Bukhs udgave afløst af en tempofyldt og friere bevægelsesgymnastik, der lagde vægt på kraftudfoldelsen.

Hvor Ollerup Gymnastikhøjskole havde drenge om vinteren og piger om sommeren, så uddannede Snoghøj kun piger. Fra midten af 1920'erne og frem til efter 2. verdenskrig var Snoghøj-gymnastikken toneangivende indenfor kvindegymnastikken i Danmark. Gymnastikstilen lagde vægt på etik og æstetik. Udgangspunktet var ligesom ved Buhks primitive gymnastik den lingske gymnastik, som blot blev moderniseret og videreudviklet.

Selv om de to højskoler havde rod i den grundtvigske højskoletradition, og begge skoler tog udgangspunkt $\mathrm{i}$ den lingske gymnastik, var de langtfra enige. I bogen Kampen om kroppen hævder Ove Korsgaard dog, at selv om de to højskoler på overfladen kan synes meget forskellige, så var lighedspunkterne mellem dem på en række områder langt større end forskellene. ${ }^{4}$ Det man var fælles om, var bl.a. betoningen af massegymnastik i det fri, hvor »opvisningerne formede sig som gymnastiske skuespil«.

Inspireret af højskoleoplevelser tog mange delingsførere ideen om udendørsopvisninger med hjem. Friluftsgymnastikkens fremmarch var dog ikke uden problemer, idet den løbende krævede nye rammer. Det samme gjorde de nye idrætsgrene, der vandt større og større indpas i gymnastikforeningerne. Det kolde forsamlingshus slog ikke længere til, og flere amts- og hovedkredse havde held til at få etableret en række udendørs gymnastik- og idrætspladser, der gerne fungerede som selvejende institutioner. Som regel var det gymnastikforeningernes medlemmer, der selv tog initiativet og selv udførte arbejdet på frivillig basis. Enkelte gange viste kom- munerne sympati for sagen, og gymnasterne fik et stykke jord eller lidt $\varnothing$ konomisk støtte til byggeriet.

De nye gymnastik- og idrætspladser, der gerne var lagt i naturskønne omgivelser, blev som regel udstyret med håndbold- og fodboldbaner, springgrave og løbebaner samt tilskuerpladser. ${ }^{5}$ Og her afholdt gymnastikforeningerne alt lige fra håndboldturneringer, sommerfester, delingsførermøder og de årlige gymnastikstævner, hvor medlemmerne viste, hvad de havde lært i vinterens løb. Mellemkrigsårenes nye gymnastik- og idrætsanlæg sikrede ikke alene gymnastikken udbredelse og gav rum for tidens masseopvisninger, men de gav også - og måske især - rum til de nye idrætsgrenes udbredelse.

Mange af mellemkrigsårenes idrætspladser på landet var børn af den folkelige, grundtvigianske gymnastikbevægelse, og de blev - ligesom forsamlingshusene - den institutionelle ramme omkring treenigheden: tale, sang og gymnastik. Gymnasternes grønne tumlepladser var udstyret med talerstol og faneplads. Det var her, man skabte og gav udtryk for sin kollektive identitet. Men idrætspladserne blev også kulturelle centre, der gav rum for folkelige manifestationer (f.eks. møder, fester, sangstævner og foredrag), som rakte langt ud over gymnasternes egne rækker.

Der foreligger ingen sikre talmæssige opgørelser over, hvor mange sådanne gymnastik- og idrætspladser, der blev etableret i de danske landsogne. Ungdom og Idraet omtaler i årene 1900-1950 hyppigt de nyetablerede pladser - specielt efter 1925 men alle blev sikkert ikke nævnt her. Meget tyder dog på, at der skete en omfattende udbygning af de sparsomme udendørsfaciliteter, der stod til rådighed for idrætten i landdistrikterne. Mange amtskredse fik 
således et udendørs samlingssted for amtskredsen.

Den kendteste af disse folkelige idrætspladser er sikkert den tidligere militærlejr ved Fugls $\varnothing$, som De danske Gymnastikforeninger købte i 1930'erne og omdannede til idrætsplads for den folkelige gymnastik. Også Fyn fik sine gymnastik- og idrætspladser. Her skal Frøbjerg Bavnehøj og andre fynske gymnastik- og idrætspladser præsenteres.

\section{Et nyt Skamlingsbanken}

Mange har i tidens løb besøgt Frøbjerg Bavnehøj, der i årtier var - og stadig er - et yndet udflugtsmål for fynboer. Der er en fantastisk udsigt fra højen, som med sine $131 \mathrm{~m}$ over havet er Fyns højeste punkt. I første del af 1900-tallet var bavnehøjen og- så kendt som en fest- og gymnastikplads, hvor der blev holdt store folkelige møder, gymnastikopvisninger og fester.

Historien om Frøbjerg Bavnehøj som idrætsplads begynder i 1910, hvor Fyns Stifts Patriotiske Selskab fejrede 100 års jubilæum. Det blev festligholdt efter alle kunstens regler, og ganske mod forventning gav arrangementet et overskud på $3.000 \mathrm{kr}$. Penge som kontorchef Johannes Kyed, Skovlund, foreslog blev brugt på en forsamlings- og mindeplads, der skulle være et fynsk sidestykke til Skamlingsbanken eller Skibelund Krat, der allerede i en årrække havde været samlingssteder for fester og folkemøder. ${ }^{6}$

Blikket blev hurtigt rettet mod Frøbjerg Bavnehøj, der ikke alene lå højt og smukt, men også var et ældgammelt kultsted for frugtbarhedsguden Freja. En komité blev

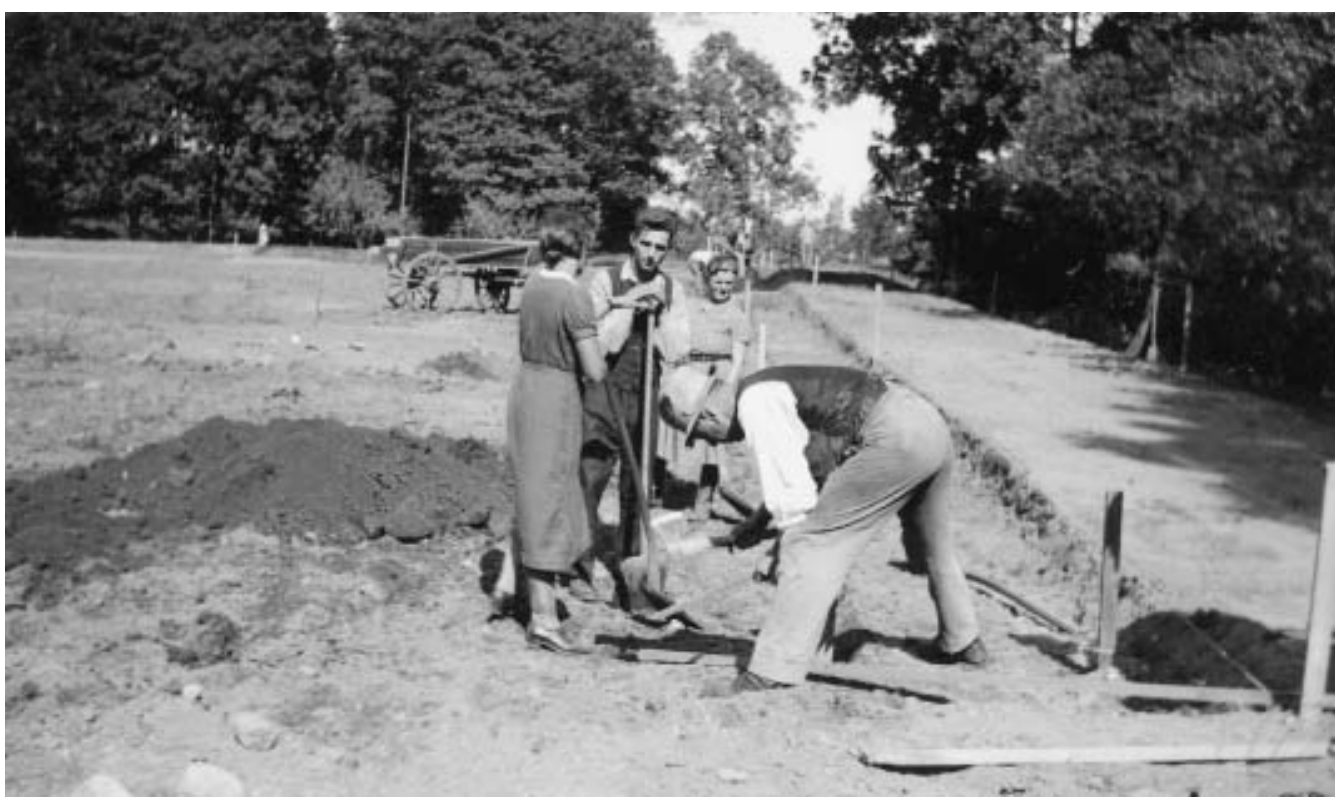

Arbejdet på idrcetspladsen i Den Gamle Have begynder i juli 1933. Pladsen måles og afmarkes. Jens Peder Jensen måler ud. Han var en fremtradende skikkelse i fynsk idratsliv i 1930'erne og 40'erne, hvor han var formand for 1. hovedkreds. Jens Peder Jensen var blandt arkitekterne bag dannelsen af De Danske Gymnastikforeninger i 1929. Han var også en ivrig debattфr i Ungdom og Idrat $i$ disse år (Stadsarkivet). 
dannet, men der savnedes dog flere penge, og derfor blev en storstilet indsamling sat $\mathrm{i}$ værk. Et opråb blev rundsendt til fynske skolelærere, højskolelærere og andre. Heri hed det bl.a., at fynboerne savner en »mindeplads, hvor stene kan tale til nuvarende og kommende slagter om tider, der svandt $\ll$. De fynske lærere blev sat til at sælge små mærker à $25 \varnothing$ re stykket, der hver gav ret til et lille stykke af bavnehøjen. Derudover donerede enkelte pengeinstitutter større pengegaver.

I foråret 1913 blev Frøbjerg BavnehøjSelskabet stiftet. De tre høje (bavnehøjen og to andre høje, der lå tæt ved) blev købt og gjort til en selvejende institution. Og så kunne arbejdet med at få omdannet højene til en mindeplads gå i gang - et arbejde, der varede frem til 1922. En københavnsk landskabsarkitekt tegnede anlægget og den odenseanske direktør Chr. Dæhnfeldt skænkede planterne. På pladsen skulle der helt $\mathrm{i}$ tidens ånd rejses mindesten for mennesker og begivenheder, som havde haft særlig betydning for Fyn - alt sammen for at fremme den historiske sans. I 1918 blev den første mindesten afsløret, som skulle minde om, at kvinderne i 1915 havde fået stemmeret, og i 1922 fulgte en genforeningssten.

I efteråret 1915 lagde Frøbjerg Bavnehøj græs til det første store folkemøde, hvor talerne var højskoleforstander Thomas Bredsdorff, Roskilde Højskole, og folketingsmand og forhenværende konseilspræsident (statsminister) Klaus Berntsen. ${ }^{7}$ Fyn havde fået det samlingssted for store møder og fester, som initiativtagerne havde $\varnothing$ nsket sig, og i de følgende år gik det slag i slag med møder. Talerne var ofte landskendte politikere og højskolefolk, der talte over folkelige emner. Ikke mindst grundlovsfesterne blev en årligt tilbagevendende tradition.

\section{Gymnastikken kommer med}

Kronen på værket kom dog først, da også gymnastikken og idrætten blev inviteret til Frøbjerg Bavnehøj. I begyndelsen af 1920'erne indledte Odense Amts Skytteog Gymnastikforening forhandlinger med Frøbjerg Bavnehøj-Selskabet om planering af et område ved Bavnehøjen. ${ }^{8}$ Da gymnastikken passede godt overens med målsætningerne for brugen af Frøbjerg Bavnehøj, blev man snart enige om at anlægge en gymnastikplads. Den kostede ca. 4.000 kr., hvoraf Bavnehøjselskabet betalte halvdelen, mens amtskredsen betalte den anden halvdel.

Den 27. juli 1924 blev det første store gymnastikstævne afholdt. Der var til lejligheden anlagt siddepladser op ad skråningerne. I alt 45 hold med 1.500 gymnaster deltog i stævnet, mens 5.-6.000 mennesker fulgte begivenhederne fra skråningerne. ${ }^{9}$

Opstemt af det vellykkede gymnastikstævne blev idrætspladsen udvidet, så der kunne være fem hold fremme ad gangen, og den 26. august 1925 gav Niels Bukh og hans Tysklandshold på 15 karle og 12 piger opvisning på Frøbjerg Bavnehøj, der snart blev amtsforeningens foretrukne samlingssted.

Gymnastikopvisningerne på Frøbjerg Bavnehøj hørte til blandt højdepunkterne i gymnastikforeningens årsrytme. Her mødtes ungdommen under vajende Dannebrogsflag og åben himmel. Et af sommerens fristeder! Her var - bogstavelig talt højt til loftet, så ungdommen kunne få luft under vingerne. Her blev man ført ind i et univers, hvor idræt og fritidsliv smeltede sammen med faner, fædrelandssange og opbyggelige foredrag.

Gennem en menneskealder var Frøbjerg Bavnehøj den folkelige idrætshøjborg på 


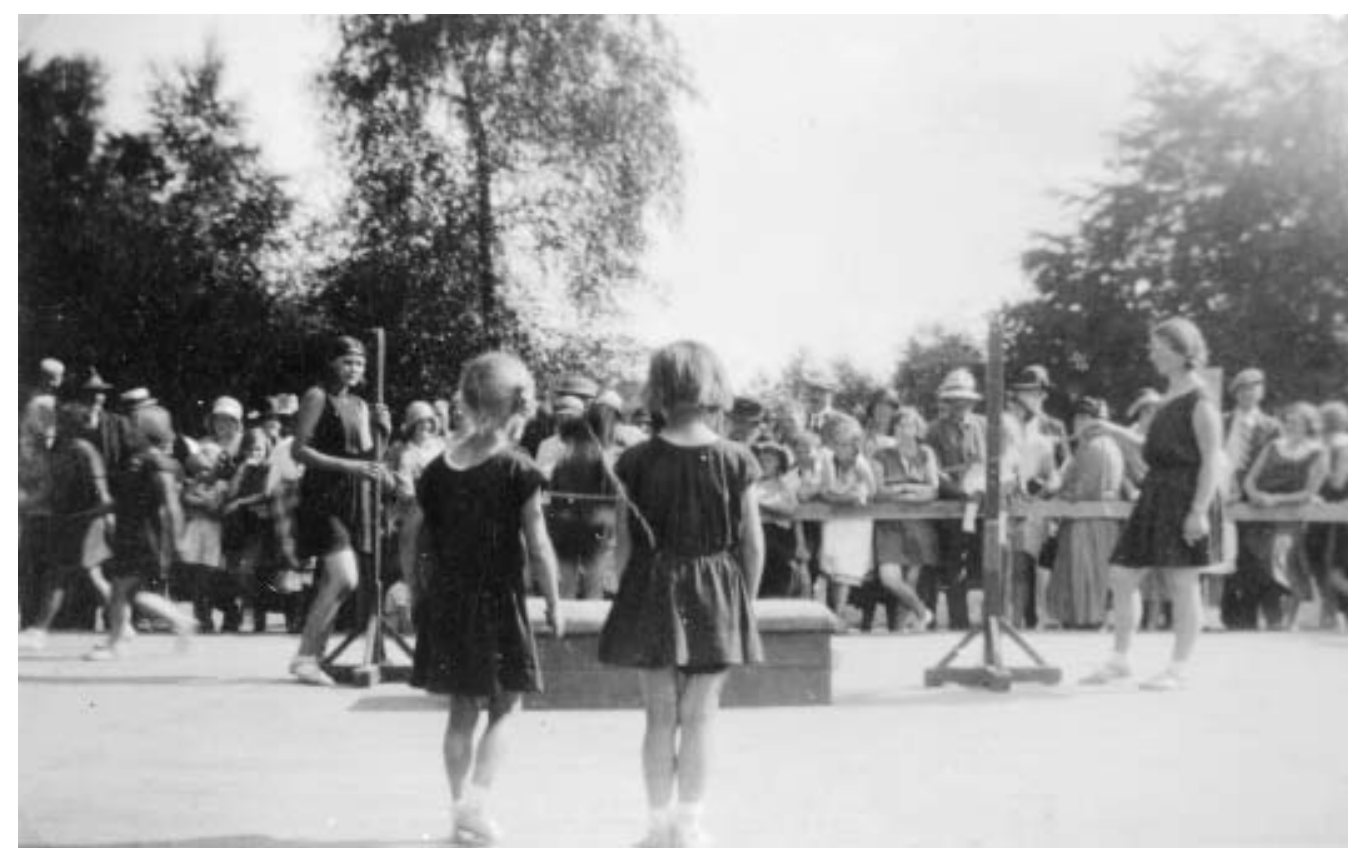

Fraugde Gymnastikforenings pigehold ved opvisning i Den Gamle Have i Allerup 15. juli 1932. Spring over hest og balance på bom blev gerne brugt til opvisninger (Stadsarkivet).

Fyn - ikke mindst, da der i 1930 blev bygget en stor hal, så folk kunne dyrke deres idræt uafhængigt af vind og vejr.

\section{Frøbjerghallen}

Vejrguderne kunne undertiden være i det drilagtige hjørne, når der blev afholdt gymnastikopvisninger. Derfor fik man den tan$\mathrm{ke}$, at der burde bygges en stor gymnastikog samlingssal ved bavnehøjens fod. Der blev atter iværksat en indsamling, der indbragte $12.000 \mathrm{kr}$., og derudover blev der lånt godt $30.000 \mathrm{kr}$. i banken. Opførelsen kostede i alt $55.000 \mathrm{kr}$ - - en anselig sum, som rundt regnet svarer til, hvad 14-15 ufaglærte mandlige arbejdere tjente på et helt år.

Frøbjerghallen blev indviet den 11. maj 1930. Den var opført i samarbejde mellem Frøbjerg Bavnehøj-Selskabet og De dan- ske Skytte- og Gymnastikforeninger, og indvielsen blev foretaget af den fynske biskop, den grundtvigianske A. J. Rud, men også skolebestyrer P .J. Skriver, Glamsbjerg Fri- og Efterskole, talte. Sidstnævnte anslog helt $\mathrm{i}$ tidens ånd en meget national tone, da han skulle indvi amtsforeningens nye fane. Han sagde bl.a.:

»Der er meget, der skiller os. Vi skilles politisk, kirkeligt og i klassemodsatninger, men er der da intet, vi kan vare falles om. Jo, der er tre ting: faedrelandet, modersmålet og flaget. Tank på faedrelandet i 1848, hvorledes det danske folk da kunne samles, og sådan gik det også i 1914. Om modersmålet synger vi et sted, at det har »himmelsk lyd «, og sønderjyderne har laert os at forstå, hvad modersmålet er vard. Også om flaget er vi falles. Herhjemme og på de fjerne have vajer det for det, der er dansk. Vi hejser det $i$ vor glade og $i$ vor sorg. Vor 
gamle fane, som vi ved delingen mellem skytter og gymnaster overlod skytterne som deres retsmassige arv, vajede over en ungdom. Lad os håbe, at den ny også må komme til at gфre det«. ${ }^{10}$

Hallen, der var opført af træ og tagpap, havde efter samtidige forhold en imponerede størrelse. Den målte ca. 50 x 22,5 m, og selve gulvet målte $38 \times 15 \mathrm{~m}$ - eller 570 $\mathrm{m}^{2}$. Der var siddepladser til i alt 1.200 personer. Langs den ene side var i hele salens længde indrettet omklædningsrum for mænd og kvinder. Hallen, der havde ovenlys og balkon, var tegnet af Odense-arkitekten Hjalmar Kjær. Der var ikke søjler eller andet støtteværk anbragt i det mægtige rum, som helt og holdent var skabt til gymnastikopvisninger.

Da folketingsmand Johannes Kyed, en af primus motorerne i hele projektet, blev spurgt om, hvad hallen kunne bruges til, lød svaret prompte: »Til oplysning og idrcet for alle [...], men ikke til offentlig dans «. ${ }^{11}$ De næste mange år var Frøbjerg Bavnehøj og den store hal et naturligt samlingssted for den folkelige idræt på Fyn. Blandt de faste brugere af hallen var 5. hovedkreds, der holdt sine årlige forårsopvisninger $\mathrm{i}$ hallen. Opvisningerne lå gerne i slutningen af april eller begyndelsen af maj, eftersom Frøbjerghallen var uopvarmet.

Sådan gik det i mange år, men om eftermiddagen den 28. januar 1959 nedbrændte Frøbjerghallen under dramatiske omstændigheder. ${ }^{12}$ Branden, der opstod i en oliekamin, satte et pludseligt og overraskende punktum for Frøbjerg Bavnehøj som centrum for den folkelige idræt på Fyn. Det viste sig, at hallen havde været forsikret alt for lavt, så der ikke var økonomisk grundlag for at genrejse hallen. Amtskredsen havde ellers været langt fremme med planer om at udbygge Frøbjerg Bavnehøj med nogle boldbaner på et nærliggende stykke jord, som allerede var købt, men de planer blev nu skrinlagt. Og snart blev Odense Amts Gymnastikforenings årlige amtsstævner også flyttet bort. Begyndelsen til enden for Frøbjerg Bavnehøj som idrætsplads for den folkelige idræt var indledt. ${ }^{13}$

\section{Den Gamle Have}

Efter Frøbjerghallens brand blev det nu Den Gamle Have ved Allerup (lidt uden for Odense), der kom til at huse de årlige amtsstævner. Det gav Den Gamle Have et voldsomt rygstød, indtil haven blev for lille, og amtsstævnerne flyttede bort i midten af 1990'erne.

Når Den Gamle Have blev til en idrætsplads, skal forklaringen søges i et voldsomt uvejr i 1912. Hele sommeren havde været plaget af skybrud og elendigt vejr, men uvejret den 28. juli overgik alt andet. Hen på eftermiddagen trak en frygtelig regnskylle med torden og lyn hen over Fyn, og et lyn slog ned i skorstenen på Allerup Skovgaard og forvandlede på et øjeblik den gamle firlængede bindingsværksgård til en rygende askehob, så der kun var grundstenene og en lille afsides liggende svinesti tilbage. ${ }^{14}$

En ny gård blev rejst ude på marken, hvor den lå mere rationelt i forhold til jorderne, men den gamle gårdhave blev stadig passet nænsomt af familien. Sådan gik der nogle år, men snart groede haven ved den ny Allerup Skovgaard op, og to store haver blev efterhånden for meget. Derfor blev den gamle gårdhave inde i landsbyen i 1929 overladt til den lokale gymnastikforening, så gymnasterne kunne bruge haven til opvisninger, møder og sommerfester.

Ved medlemmernes indsats fik Allerup Gymnastikforening omskabt haven til en lille græsplæne, som kunne gøre det ud for en idrætsplads, hvor de lokale gymnaster 
slog deres vejrmøller og kraftspring. Plænen lagde de følgende år græs til flere opvisninger, og ved et sådan sommerarrangement var formanden for Odense Amts Gymnastikforenings 1. hovedkreds, gårdejer Jens Peder Jensen fra Lumby pr. Årslev, indbudt. Han syntes vældig godt om gymnastikpladsen, og snart blev ideen om at gøre Den Gamle Have til en fast fest- og idrætsplads for hele 1 . hovedkreds fostret. I juni 1933 gik arbejdet med at udskrive frivilligt mandskab fra de mange lokalkredse i gang, og på ingen tid var der skrabet adskillige arbejdshold à 15 mænd sammen. Hvert hold mødte med spader og skovle, mens Allerupbønderne og folk fra de nærmeste kredse sendte tre forspændte arbejdsvogne til pladsen. Efter 32 arbejdsdage var ca. 4.500 vognlæs - eller flere tusinde kubikmeter jord - flyttet. Flere tusinde frivillige arbejdstimer var brugt på at få skabt en ny og større fest- og idrætsplads.
Det hele kostede 1.000 kr., som blev brugt til indk $\varnothing b$ af græs og til løn til en entreprenørformand, den eneste lønudgift, der var ved arbejdet.

\section{Frisk luft og frisk vand}

Allerede før den nye idrætsplads blev indviet, dukkede der andre og større planer op for Den Gamle Have. Der skulle også bygges et svømmebassin. Tanken om et friluftsbad i haven var ikke ny, men havde svirret i luften siden 1932. Hidtil var planen dog blevet udskudt.

Rundt om i landet var der i 1930'erne en vældig interesse for friluftsbade, og år for år skød nye svømmebassiner op. I Engesvang ved Silkeborg havde Gl. Skanderborg Amts Gymnastikforening fået Jyllands første udendørsbad i 1930. Og ideen fra Engesvangbadet smittede af. Folk med interesse for ungdomsarbejdet blev impo-

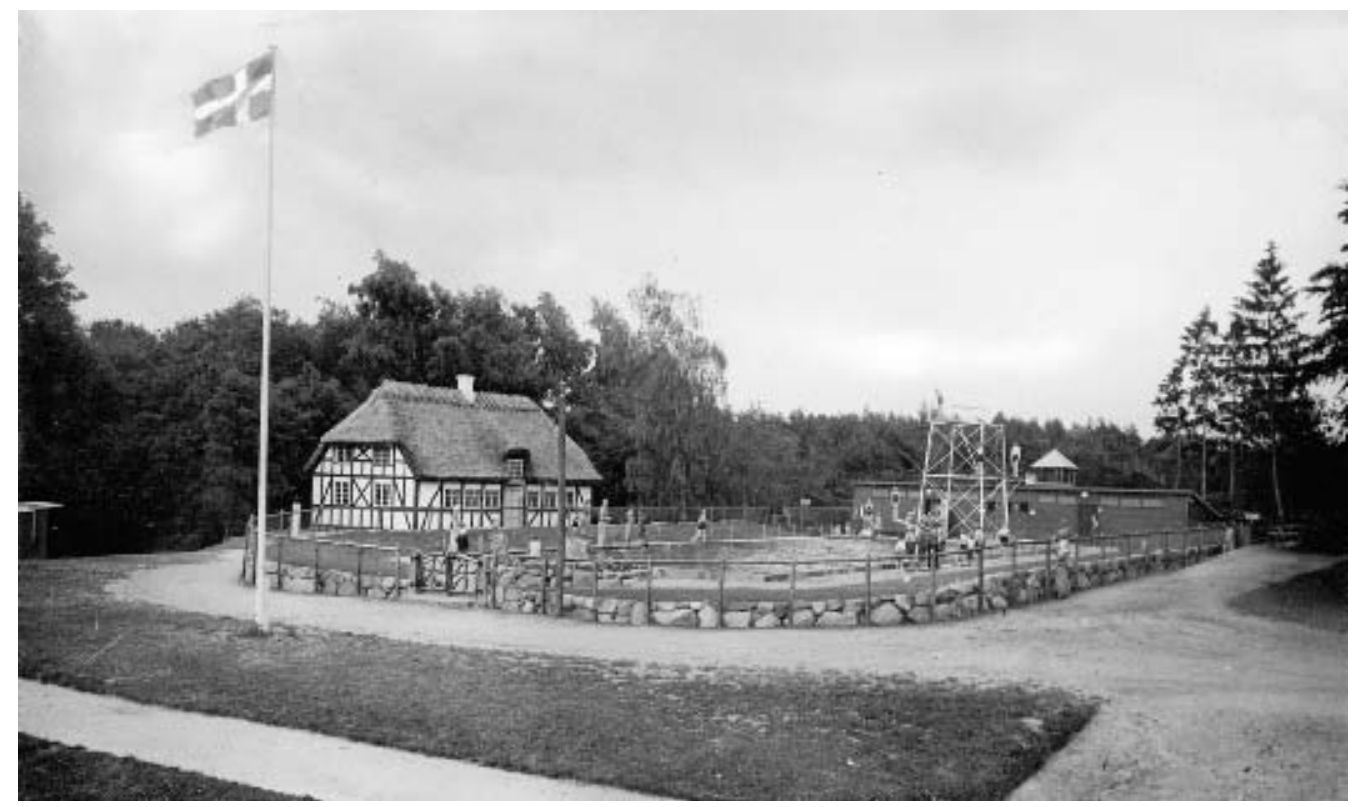

Sommerdag i Den Gamle Have i Allerup, ca. 1935. Haven var ikke alene samlingssted for gymnaster og andre idrcetsudøvere, men også et fristed for lokalområdets børn og unge. (Stadsarkivet). 
neret over synet, og snart dukkede andre friluftsbade op, så lokalbefolkningen »til gavn for sundhed og renlighed « ikke længere skulle bade i åer og mergelgrave. De »kunstigt « anlagte bassiner blev ofte rost, da vandkvaliteten var renere end ved f.eks. de mange strandbade. I Ungdom og Idrat blev der ofte talt om svømning som et nyt vigtigt krydderi i foreningernes arbejde med ungdommen. ${ }^{15}$

Også på Fyn var interessen for et svømmebad vakt. Da friluftsbadet blev drøftet i bestyrelsen for 1 . hovedkreds, mødte det megen sympati, men eftersom bassinet fortrinsvis ville komme de nærmestboende gymnastikkredse til gode, blev det også disse, der skulle bære byrden. Gymnasterne fandt atter skovl og spade frem og tog endnu en tørn.

Svømmebassinet, hvis forbillede var Ugerløse Svømmebassin ved Holbæk, stod snart klar, og søndag den 8. juli 1934 slog Den Gamle Have dørene op med idrætsplads og svømmebassin.

I Den Gamle Have udfoldede der sig et vidtforgrenet fritidsliv - og ikke mindst det lokale idrætsliv nød godt af Den Gamle Have. Her var der mulighed for at dyrke de nye idrætsgrene, som fra 1930'erne for alvor vandt indpas i gymnastikforeningerne. Ved stævnerne blev der nu vist både boldspil, folkedans, svømning og meget andet. Friluftsbadet var selvsagt Den Gamle Haves store trækplaster. Allerede den første dag strømmede badegæsterne fra nær og fjern til bassinet, og sommeren igennem blev bassinet flittigt brugt af den lokale befolkning. Af de 450 mennesker, der boede i Allerup sogn, havde 155 løst sæsonkort det første år - eller ca. 33\% af alle de folk, der boede inden for en radius af $2 \mathrm{~km}$ fra badet. Et sæsonkort kostede $5 \mathrm{kr}$. for voksne og $3 \mathrm{kr}$. for børn, mens voksne måtte slippe 2,50 kr. for et månedskort, mens det koste- de 1,50 kr. for børn. Prisen for et enkelt bad var henholdsvis $50 \varnothing \mathrm{re}$ og $25 \varnothing \mathrm{re}$.

Da nyhedens interesse havde lagt sig, faldt antallet af besøgende ganske naturligt i det uopvarmede badebassin. Mens der blev solgt færre sæsonkort både til voksne og børn, blev der derimod langet flere ugekort og enkeltbilletter over disken.

Et varmt emne i tidens offentlige debat var spørgsmålet om »fællesbadning « - eller adskilte badetider for mænd og kvinder, og hvorvidt fællesbadning var moralsk forsvarlig. I Den Gamle Have var der fællesbadning, men det krævede »kontrol, og endda en tilstrakkelig myndig kontrol «, som altid skulle håndhæves i badetiden, »så den allermindste spire til dårlig tone eller ukorrekt optrceden kvales omgående«. ${ }^{16}$ Hvis kontrollen bare var i orden, og det skulle den selvfølgelig være, så var fællesbadning en naturlig selvfølge, mente folkene i Allerup.

Et sæt ordensregler skulle sikre, at kontrollen blev holdt. Det var blandt andet forbudt at svømme ud i den dybe del, hvis man ikke var en aldeles sikker svømmer. Gæsterne måtte heller ikke slås eller dukke andre under vandet. Det var forbudt at råbe og skrige uden grund, og ingen måtte »flirte eller dyrke selskabelighed i badedragt « - hvorfor badegæsterne heller ikke måtte færdes på gangene i skoven i badet $\varnothing \mathrm{j}$ ! Ordensreglerne var trykt på bagsiden af alle sæson- og månedskortene, og bademesteren førte tilsyn med reglernes overholdelse.

\section{Ungdommens haver}

Med Den Gamle Have fik landsbyen Allerup, som blot talte nogle få hundrede hoveder, en »attraktion «, der tiltrak folk fra nær og fjern. Hvor vinterens gymnastik i forsamlingshuset var »indelukket«, var aktiviteterne i f.eks. Den Gamle 


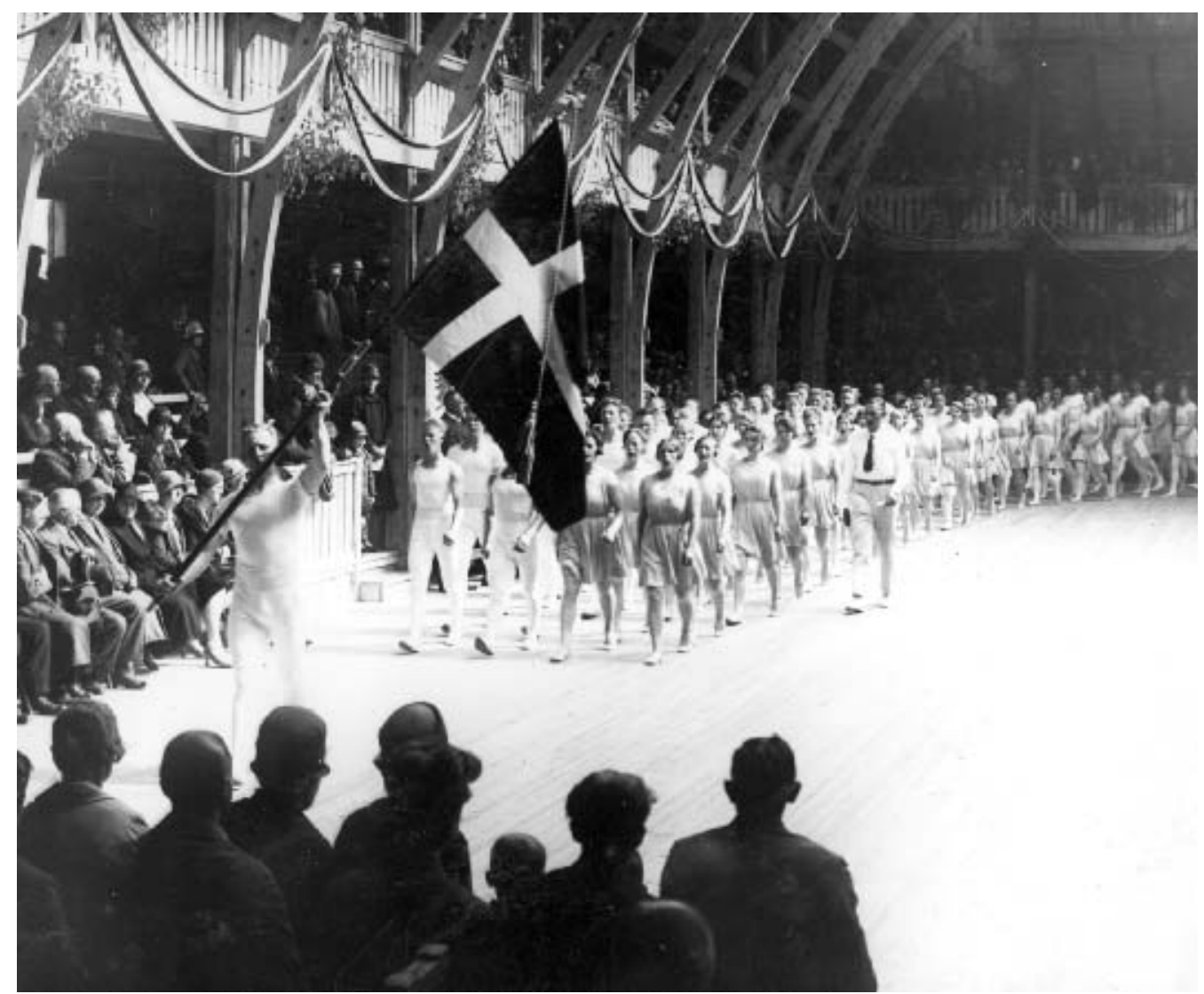

Indvielse af gymnastikhal ved Frøbjerg Bavnehøj i 1930. Foto: Vartov-Arkivet.

Have og på Frøbjerg Bavnehøj »åbne«. Her samledes folk fra alle nabolandsbyerne. Folk rejste for at komme i Den Gamle Have eller på Frøbjerg Bavnehøj. Her mødte man de andre og fik sit erfaringsgrundlag udvidet.

Når man læser og hører beskrivelser om livet i og omkring disse fest- og gymnastikpladser, fornemmer man hurtigt, hvor stor og afgørende betydning for folks liv, Den Gamle Have, Frøbjerg Bavnehøj eller andre pladser har haft. Mange oplevelser knytter sig til stederne.

Frøbjerg Bavnehøj og Den Gamle Have var utvivlsomt de største og kendteste af de folkelige idrætspladser på Fyn. På Nordfyn holdt gymnasterne i mellemkrigsårene f.eks. til i Glavendruplund, ved den kendte Glavendrupsten. Her var i 1906 indrettet en festplads, hvor der også blev opført en træhal med 800 siddepladser. På festpladsen var der - ligesom på Frøbjerg Bavne$h ø j$ - rejst en række mindesten.

På Vestfyn holdt gymnasterne til ved Båring Skov, Asperup Sogn, hvor man i 1928 købte Odense Politis sommer- og rekreationshjem for $2.200 \mathrm{kr}$. Fra købet i 1928 og op gennem 1930'erne og 1940'erne blev stedet udbygget med hus, opvisningsplads og håndboldbane.

Overalt på Fyn skød der sådanne idrætsanlæg op, hvor der var tilgængelige res- 
sourcer, det befolkningsmæssige underlag, lederskab og vilje. Disse ungdommens haver blev overvejende brugt til gymnastikopvisninger, men spillede også en vigtig rolle i udbredelsen af nye idrætsgrene. Da de fynske landsogne i 1930'erne fik smag for håndbold, blev Den Gamle Have og Frøbjerg Bavnehøj eksempelvis naturlige omdrejningspunkter for spillets udbredelse. Det første amtsstævne i håndbold blev således afholdt på Frøbjerg Bavnehøj i 1936 med 15 hold. Efter stævnet oprettede flere hovedkredse særlige håndboldudvalg, der skulle fremme spillets udbredelse i gymnastikkredsene.

\section{Perspektivering}

Den folkelige idræts udbredelse og fornyelse i mellemkrigsårene var langt hen ad vejen betinget af nye idrætspladser - som f.eks. Frøbjerg Bavnehøj og Den Gamle Have i Allerup. Uden dem kunne f.eks. håndbolden næppe have gået sin sejrsgang så hurtigt, og uden friluftsbadene havde så mange landboere næppe lært at svømme. De nyetablerede idrætspladser kom automatisk til at indtage en, central rolle i det netværk af idrætsstævne, gymnastikopvisninger og sportsfester, der så dagens lys i mellemkrigsårene.

De, der kom til gymnastikpladserne for at lave opvisninger, oplevede en fornemmelse af at være med i en større sammenhæng, en del af et organiseret fællesskab med den folkelige idræt som omdrejningspunkt. Her blev der sat ansigt på fællesskabet, og her mødte man »den levende idræt «. Gymnastikpladserne fungerede som arena for tidens landbokultur. På grønsværen lærte folk om fællesskab og om kombinationen mellem det sociale og det individuelle. Her fik gymnasterne den folkelige idræts myter og ritualer ind under huden. ${ }^{17}$
Det, der karakteriserede den moderne gymnastik- og idrætsbevægelse var netop, at den adskilte sig fra dagligdagen - både konkret i form af gymnastikkens bestemte rum og i væsen, idet gymnasterne (og for den sags skyld også tilskuerne) trådte ud af deres bestemte positioner i samfundet, når de trådte ind på idrætspladsen. Alle deltagere var i princippet lige. Gennem denne adskillelse kunne gymnastikken og idrætten forme sine egne ritualer og sine egne myter.

De mange nye idrætspladser, der dukkede op i landsognene, havde ikke bare stor betydning for gymnastikforeningernes udfoldelsesmuligheder men også for der selvværd og selvopfattelse. I Den danske idrats bog fra 1935 lyder den højstemte vurdering fra A. Pedersen Dømmestrup, der var redaktør af Ungdom og Idrat, bl.a. sådan:

$\gg$ Foruden at afholde gymnastikfester og delingsførermфder har amter og hovedkredse i løbet af de sidste 3-4 år påtaget sig og lost store og betydningsfulde opgaver. Ved initiativ fra ledelsens side og interesse fra ungdommens side er det lykkedes rundt om i landet at indrette en maengde lejr-, festog idrcetspladser. I de allerfleste tilfcelde har de unge selv udfort disse arbejder, der langt frem i tiden vil stå som et vidnesbyrd om, at hvor der er vilje til det, kan der udrettes noget stort, selv med små midler ${ }^{18}{ }^{18}$

De folkelige idrætspladser var med andre ord monumenter over den folkelige idræts formåen. Her kunne ungdommen sommeren igennem samles til »muntret arbejde eller fest «. Også hos de gymnaster satte mødet med idrætspladsen sig dybe spor. En kvindelig deltager fra børnestævnerne i Den Gamle Have i 1930'erne fortæller:

»Omkladning foregik $i$ de forste år på Allerup Skovgårds loft og i stalden. Derefter stillede vi op på gårdspladsen, før der 
var afgang til idratspladsen, hvor der var hejst flag omkring grasplanen. Med faner og musik $i$ spidsen marcherede vi i flok til haven, hvor der var indmarch. Så fulgte flaghejsning af det store flag, sang og velkomsttale ved formanden $i$. hovedkreds Jens Peter Jensen. Til sidst blev alle fanerne samlet $i$ en faneborg ${ }^{19}{ }^{19}$

For omegnens unge blev eksempelvis Den Gamle Have et tilholdssted - et fristed om sommeren. Her trænede den lokale idrætsforening, Allerup Skytte- og Gymnastikforening, og her holdt foreningen sine små håndboldstævner med efterfølgende dans for de indbudte foreninger. Gennem hele sommeren var haven foreningens omdrejningspunkt - og holdepunkt.

En kvinde, der i midten af 1930'erne tjente på en gård nær Den Gamle Have, fortæller:

»På hverdage kunne jeg, når klokken var henad 8 om aftenen, og alle de huslige pligter var ordnet, gå over $i$ haven. Det blev ofte til en svommetur - faktisk larte jeg at svфmme i Den gamle Have. Det var

\section{Noter}

1 Ungdom og Idrat (1933), s. $532 \mathrm{f}$.

2 Niels Kayser Nielsen (red.): Håndbold i 100 år et overblik (Svendborg, 1997), s. 68ff.

3 Henning Eichberg og Eigil Jespersen: De grønne bølger. Træk af natur- og fritidslivets historie (1986), s. 204ff.

4 Ove Korsgaard: Kampen om kroppen (København 1982 ), s. 241.

5 Se eksempelvis Ungdom og Idrat (1933), s. 188f., 272f., 308 og 462ff.

6 Skibelund Krat ved Askov blev efter krigen 1864 et nyt sted til fester og folkemøder, der før krigen blev holdt af lærer i Rødding. Krattet gav siden plads for mange grundlovs- og folkemøder og blev tillige mindeplads med en række mindesten.

7 Aarsskrift. Udgivet af Glamsbjerg Friskoles Elevforening. Glamsbjerg 1926, s. 4ff. bademesteren Ole Mфller Kristensen, der larte mig det. De lyse sommeraftener gav os unge masser af tid til at sidde og snakke. Der var masser af sjov, og af og til var der også et ungt par, der forsvandt i skoven «. ${ }^{20}$ Som man fornemmer på citatet, så samledes idrætsfolkene på græsværen eller ved bassinkanten med andre unge til fornøjeligt samvær. Her fik man kammerater for livet, enkelte fik måske også en kæreste. Man indgik i et fællesskab med andre unge - og havde det sjovt.

Der var ikke mange fritids- og idrætstilbud i Allerup og de andre omkringliggende landsbyer, men i de lange sommerdage gav Den Gamle Have egnens landboungdom mulighed for at komme lidt ud - at få luft under vingerne uden for gårdens eller karlekammerets fire vægge.

På idrætspladserne mødtes omegnens unge på deres frisøndage for at lave opvisninger og spille turneringer. De nye idrætsanlæg var med til at sikre ikke alene gymnastikken, men også - og måske især - de nye idrætsgrenes udbredelse.

8 Evald Andersen: »Bidrag til Frøbjerg Bavnehфjs historie i det 20. århundrede«. I: Vestfynsk Hjemstavn (Odense, 2000).

9 Fyns Tidende 28. juli 1924.

10 Fyens Stiftstidende den 12.5.1930.

11 Fyens Stiftstidende den 3.5.1930.

12 Fyens Stiftstidende den 29.1.1959.

13 Se Forhandlingsprotokol for Odense Amts Gymnastikforening 1930-60 samt Evald Andersen op. cit.12 Fyns Tidende 29.7.1912.

14 Se f.eks. Ungdom og Idræt, 38. årg. (1934), nr. 30, s. 379 f. Se i øvrigt Johnny Wøllekær: Jeg ved, hvor der findes en have så skфn. Historien om Den gamle Have i Allerup (Odense, 2003).

15 Ungdom og Idrat, 39. årg. (1935), nr. 21, s. 249.

16 Johnny Wøllekær: Jeg ved, hvor der findes en have så skøn. Historien om Den gamle Have i Allerup (Odense, 2003) 
17 Niels Kayser Nielsen: Krop og kulturanalyse (Odense, 1997), s. 125.

18 Aage Hermann og Evald Andersen: Den danske idrats bog (København, 1935), s. Xxx

\section{Litteratur}

Evald Andersen: »Bidrag til Frøbjerg Bavnehøjs historie i det 20. århundrede«. I: Vestfynsk Hjemstavn (2000).

Henning Eichberg og Eigil Jespersen: De grønne bølger. Trak af natur-og fritidslivets historie (Baunebanke, 1986).

John Engelbrecht: Vil du tæende, må du brande (xxx, 1989).

Edith Filskov: Odense Amts Gymnastikforening 1929-1979, 50 års jubilaeum (Småtryk Odense, 1979).

Hans Henrik Jacobsen: Odense Amts Skytteforening 1866-1991 (Odense, 1991).

Ove Korsgaard: Kampen om kroppen (København, 1982).

Else Trangbæk (red.): Dansk idratsliv. Bd. 1-2, (Viborg, 1995).

Johnny Wøllekær: »Gymnaster blandt skytter«. I: Idratshistorisk Årbog (Viborg, 1992).
19 Johanne Marie Top Christensens erindring (Odense Stadsarkiv).

20 Inga Hansens erindringer (interview) (Odense Stadsarkiv).

Johnny Wøllekær: Odense $i$ bevagelse (Odense, 2001).

Johnny Wøllekær: Jeg ved, hvor der findes en have så skøn. Historien om Den gamle Have i Allerup (Odense, 2003).

Bent Ødegaard m.fl.: Højby Skytte- og Gymnastikforening 1866-1991 (Odense, 1991).

\section{Kilder, tidsskrifter m.m.}

Fyens Stiftstidende diverse årgange fra 1930'erne Fyns Venstreblad diverse årgange fra 1930'erne Fyns Tidende diverse årgange fra 1930'erne Ungdom og Idræt diverse årgange fra 1930'erne Diverse erindringer (Odense Stadsarkiv)

Allerup Skytte- og Gymnastikforenings arkiv (Odense Stadsarkiv) Odense Amts Gymnastikforenings arkiv 1. hovedkreds « arkiv (Landsarkivet for Fyn) Forhandlingsprotokol for OAG 1. hovedkreds håndboldudvalg 1942-1971 (Landsarkivet for Fyn) 